\title{
表在性膀胱腫瘍の再発率に関する検討
}

$\begin{array}{cllll} & \text { 松 } & \text { 岡 } & & \text { 啓 } \\ & \text { 植 } & \text { 田 } & \text { 省 } & \text { 吾 } \\ \text { 久留米大学医学部泌尿器科学講座 } & \text { 大 } & \text { 藪 } & \text { 裕 } & \text { 司 } \\ & \text { 藤 } & \text { 井 } & \text { 善 } & \text { 隆 } \\ & \text { 野 } & \text { 田 } & \text { 進 } & \text { 士 } \\ & \text { 江 } & \text { 藤 } & \text { 耕 } & \text { 作 }\end{array}$

\section{STATISTICAL STUDIES ON RECURRENCE RATE OF SUPERFICIAL BLADDER TUMOR}

\author{
Kei Matsuoka, Shogo Ueda, Yuuji Ooyabu, Yoshitaka Fujii, \\ Shinshi Noda and Kosaku Eto \\ Department of Urology, School of Medicine, Kurume University
}

(Director: Prof. K. Eto)

Superficial bladder tumors of the stages of T2 or below pT2 were studied in 161 patients admitted and treated in our Department with special reference to the recurrence rate. The recurrence rate was determined by the actuarial method and tested by $\chi^{2}$ test.

1. Superficial bladder tumors as a whole tended to show a markedly high recurrence rate in $0.5-$ 1.5 years.

2. When compared between the papillary and non-papillary tumors and between the mono- and multi-tumors, no significant differences were noted in the recurrence rate.

3. When analyzed from the histological stage, pT1 showed a significantly higher recurrence rate in 2-4 years compared to $\mathrm{pT}$ Tis. However, no significant differences were found in other stages.

4. When analyzed from the histological grade, a significantly higher recurrence rate was demonstrated by G3 in 1-1.5 years compared to G0, G1 and G2, and by G2 in 3-4 years compared to G0.

5. When viewed from the opeartive technique, there were no significant differences in the recurrence rate as to the type of surgical techniques. Oral administration of SLA combined with intravesicular instillation of antitumor agents had an effect of prolonging the non-recurrence duration.

6. Early postoperative intravesicular instillation of anti-tumor agents to be continued by long-term intermittent instillation is considered desirable for the control of tumor recurrence.

要旨：当科において入院治療した $\mathrm{T} 2$ または $\mathrm{pT} 2$ 以下の表在性膀胼腫瘍 161 例を集計し，特に再発率につ いて分析検討し以下の結果を得た。再発率は actuarial method, 各期間での再発率については $\mathrm{X}^{2}$ 検定を 行なった。

1. 表在性膀胱腫瘍全体に括いて，0.5 1.5年に著明な再発傾向を示した.

2. 乳頭状, 非乳頭状に扣いて，また単発，多発に扔いては再発率に有意差を認めなかった。

3. 組織学的深達度に拈いて，2 4 年では pT1は pTis より有意な再発傾向を示したが，それ以外で は再発率に有意差を認めなかった。

4. 組織学的異型度において, $1 \sim 1.5$ 年で G3は G0, G1, G2 に対し, $3 \sim 4$ 年で G2は G0に対し有意 な再発傾向を示した。

5. 手術術式においては，各術式間の再発率に有意差を認めなかったが，手術にSLA の内服と膀注を 加えることにより再発防止期間の延長が認められた。 
6. 腫瘍再発を抑制するためには，術後なるべく早期に膀注療法を開始し，長期に互る間歇的継続投与 が望ましいと考光る。

\section{緒 言}

表在性膀胀腫瘍の予後は比較的良好であるが再発し 易く，再発を繰り返すことにより深達度，異型度が増 し，予後不良となることはよく経験することである。 再発が予知できれば，治療や再発防止の方法もょり 積極的に施行でき，予後の改善が期待できると考光る.

著者らは，当科に扣いて入院治療した表在性膀胱腫 湟患者161例を集計し，再発率を検討し，再発に影響を 及ぼす因子および治療効果について若干の知見を得た ので報告する。

\section{対象および方法}

久留米大学泌尿器科に打いて，1972年 1 月より 10 年 間に入院治療した原発性膀朕腫瘍患者248例のらち, 臨 床的または病理組織学的に T2以下と認められた初回 治療例161例を対象とした。 その内訳は男子123例，女 子 38 例（男女比 $3.4: 1$ ) で，年齢分布は60代に最も多 く，次いで50代，70代と，50７0代に集中していた (Table 1). 組織学的には移行上皮癌 127 例, 扁平上皮 癌 4 例, 腺癌 1 例, 混合型10例, 不詳19例であった。

観察期間は，何らかの方法で tumor free とした後, 非再発例は tumor free と確認できた期間を，再発例は 次回再発までの期間を観察期間とした。ただし tumor free とした後 3 カ月以内の再発例, 癌あり生存例など は対象より除外した。

検討した項目は, 増殖様式, 数, 大きさ，深達度， 異型度, 術式, 術式+再発防止処置の 7 因子で各因子 に打ける再発率を Actuarial method ${ }^{1}$ によって算出 し，各期間での再発率については $\chi^{2}$ 検定を行なった。

Table 1 Cases of Superficial bladder tumor

\begin{tabular}{lll}
\hline male & 123 cases & 3.4 \\
& & $:$ \\
female & 38 cases & 1 \\
age & $0-30$ & 3 \\
& $30-40$ & 1 \\
& $40-50$ & 16 \\
& $50-60$ & 43 \\
& $60-70$ & 52 \\
& $70-80$ & 37 \\
& $80-90$ & 8 \\
& $90-100$ & 1 \\
\cline { 2 - 2 } & total & 161 \\
\hline
\end{tabular}

な怙膀胱腫瘍の臨床および病理組織学的事項は, 泌 尿器科. 病理膀胼癌取り扱い規約 21 に従い記載した。

\section{結果}

1）全症例の再発率 (Fig. 1)

対象 161 例の各期間までの再発率は 6 カ月 : $5.4 \%$, 1 年 : $27.4 \%, 1.5$ 年 : $39.5 \%, 2$ 年 : $44.6 \%, 3$ 年 : $58.7 \%, 4$ 年 $: 60.7 \%, 5$ 年 8 年 : $67.3 \%$ で, 6 力

Fig. 1 Duration of interval free of disease for all patients with superficial bladder tumor

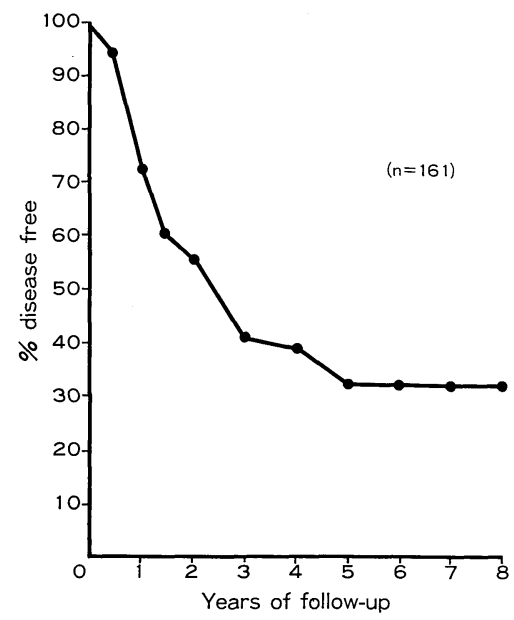

Fig. 2 Duration of interval free of disease according to form

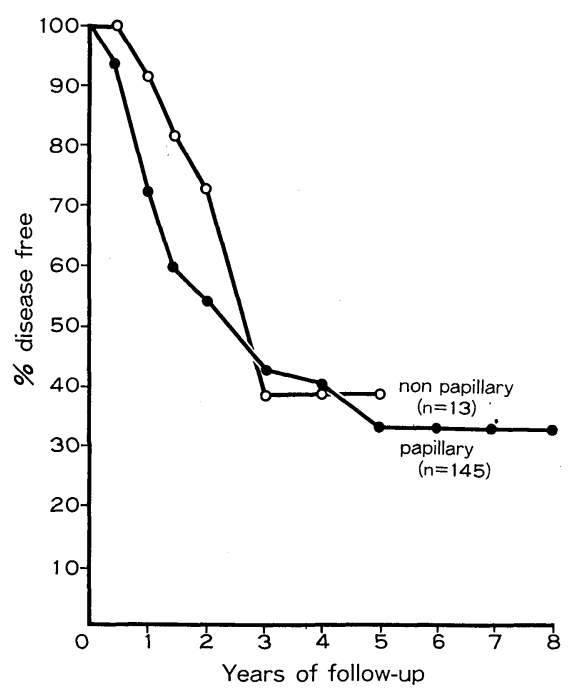


月以降 1.5 年の間に招いて再発頻度が高かった。

2) 腫瘍の増殖様式と再発率 (Fig. 2)

増殖様式では, 乳頭状腫瘍145例 (90.1\%) と非乳頭 状腫瘍13例 (8.1\%) について検討した。すすなわち乳頭 状腫場の 1 年, 2 年， 3 年までの再発率は，それぞれ $28.2 \% ， 45.7 \% ， 56.8 \%$ で，非乳頭状腫揚のそれは， $7.7 \%, 27.7 \%, 61.1 \%$ であった。 2 年までは，乳頭状 腫瘍が非乳頭状腫瘍に比して再発率が高いが，各期間 に打いて二群間の有意差は認めなかった。

3）腫瘍の数と再発率 (Fig. 3)

Fig. 3 Duration of interval free of disease according to number

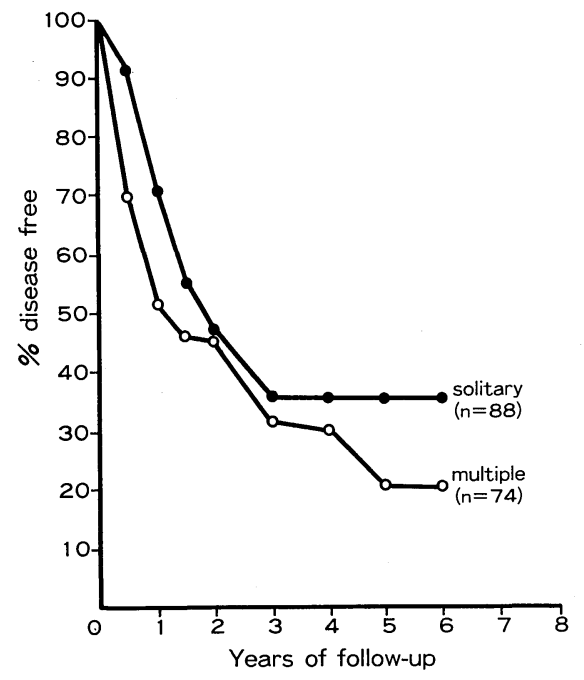

Fig. 4 Duration of interval free of disease according to size

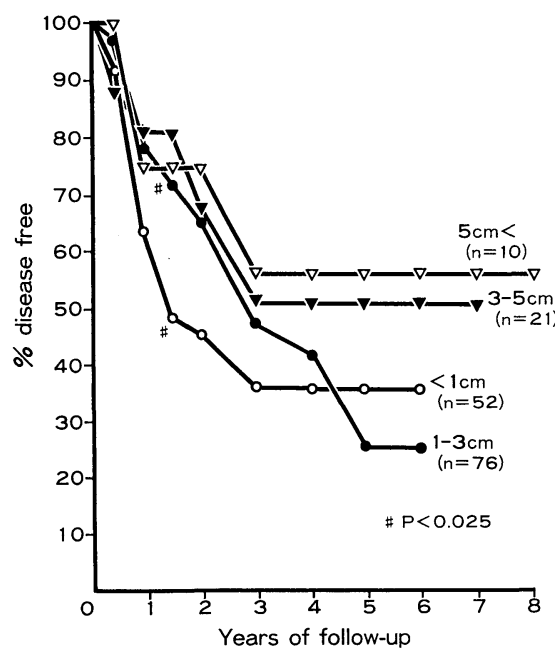

単発87例 $(54 \%)$ ，多発74例 $(46 \%)$ の分布を示し, 単発群の再発率は 1 年 : $28.9 \%, 2$ 年 $: 52.8 \%, 3$ 年 ～ 6 年: $63.7 \%$ で, 多発群では 1 年: $46.1 \%, 2$ 年 : $53.9 \%, 3$ 年 : $66.2 \%, 4$ 年 : $68.8 \% ， 5$ 年 6 年 : $77.1 \%$ であり, 各期間に打ける再発率は多発群が高く, 特に1.5年までにその傾向が強かったが二群間の検定 にて各期間での有意差は認められなかった。

4）腫湯の大きさと再発率 (Fig. 4)

$1 \mathrm{~cm}$ 以下の腫瘍は 52 例 $(32.3 \%), 1 \sim 3 \mathrm{~cm}$ は76例 (47.2\%)，3〜 $5 \mathrm{~cm}$ は21例 $(13.1 \%) 5 \mathrm{~cm}$ 以上は 10 例 (6.2\%)であった。 1 年, 2 年, 3 年までの再発率は, $1 \mathrm{~cm}$ 以下が $36.8 \% ， 55.1 \% ， 64.1 \%$ で，1〜3cm が $21.8 \%, 34.5 \%, 53.2 \%, 3 \sim 5 \mathrm{~cm}$ が $18.8 \%, 32.4 \%$, $49.3 \%, 5 \mathrm{~cm}$ 以上は $25 \% ， 25 \% ， 44.7 \%$ でった。各 期間に括いて, $1 \mathrm{~cm}$ 以下の腫瘍の再発率が高く，特に 2 年までに扔いて著しい。また 1.5 年までにおいては1 $\mathrm{cm}$ 以下と $1 \sim 3 \mathrm{~cm}$ の二群間に有意差を認めた。他の群 間には，有意差を認めなかった。

5）腫瘍の深達度と再発率（Fig. 5)

組織学的深達度に対する再発率を検討した. pTis は 8 例 (5\%), pTaは31例 (19.3\%), pT1は68例 (42.2\%), pT2は24例(14.9\%), pTxは30例(18.6\%) の分布を示した。 その再発率は，pTisに拈いて 1 年： $14.3 \%, 2$ 年 6 年 : $31.4 \%$ で, pTaに拈いて 1 年 : $26.3 \%, 2$ 年 $: 41.6 \%, 3$ 年 6 年 $: 51.1 \%$ で, pT 1 に 打いて 1 年: $29.4 \%, 2$ 年: $39 \%, 3$ 年 4 年: $39.2 \%, 5$ 年 8 年: $56.3 \%$ で, pT 2 に执いて 1 年：

Fig. 5 Duration of interval free of disease according to $\mathrm{pT}$

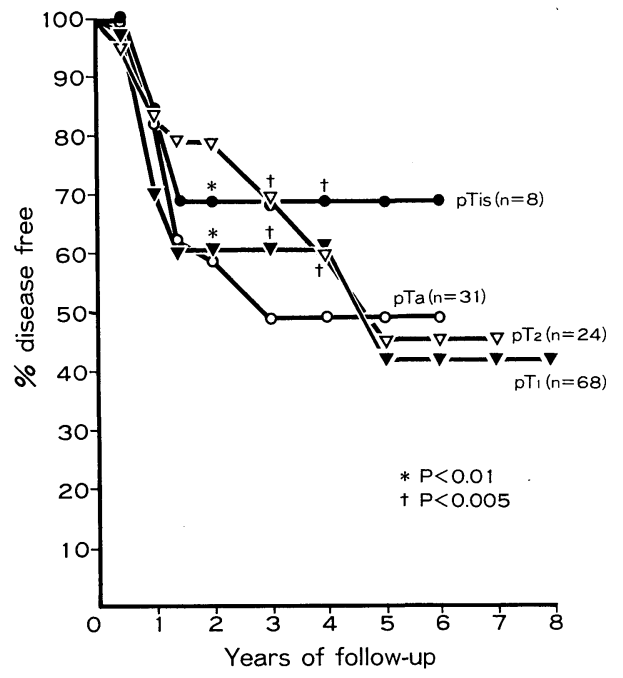


$14.9 \%, 2$ 年 $: 21.2 \%, 3$ 年 $: 30.5 \%, 4$ 年 $: 41.2 \%$, 5 年〜 7 年: $54.3 \%$ であった。

$\mathrm{pT} 1$ 群は $\mathrm{pT}$ is 群に比較して, 2 年〜 4 年において有 意な再発傾向を示した。

6) 腫瘍の異型度と再発率 (Fig. 6)

G0は11例 (6.8\%), G1は50例 (31.1\%), G2は52例 (32.3\%), G3は21例 (13\%), GX は27例 (16.8\%)の 分布であった. 再発率は, G0に拈いては 1 年：0\%, 2 年〜 6 年 : $22.2 \%$ で, G1に打いては 1 年: $17.3 \%$, 2 年 : $27.8 \%, 3$ 年 $: 45.8 \%, 4$ 年 7 年: $51.5 \%$ で, G2に挹いては 1 年 : $24.6 \%, 2$ 年 : $44.3 \%, 3$ 年〜 4 年: $65.5 \%, 5$ 年〜 6 年 : $75.4 \%$ で, G3に打いては 1 年：70.6\%, 1.5年：94.1\%であった。異型度の上昇と ともに再発率が高く, 特に 1 年から 1.5 年までに数い て, G3と $\mathrm{G} 0, \mathrm{G} 1, \mathrm{G} 2$ の各群に, 3 年から 4 年までにお いて，G2と G0との間に有意差が認められた。

7) 手術術式と再発率 (Fig. 7)

TUC 5例 ( $3 \%$ ), TUR 86例 (53.4\%), 膀胱高位 切開腫瘍切除術19例 (11.8\%), 部分切除術31例 (19.3\%) について検討した.

再発率は, TUCに扣いては 1 年 : $40 \%, 2$ 年 : $60 \%$ で, TURに拈いては 1 年: $34 \%, 2$ 年 $: 46.3 \%, 3$ 年 $\sim 4$ 年: $63.7 \%, 5$ 年 6 年 : $70.3 \%$ で, 高位切開腫 瘍切除術に怙いては 1 年: $30 \%, 2$ 年 : $55.2 \%$ で, 3 年: $66.4 \%, 4$ 年 5 年: $83.2 \%$ で, 部分切除術に括

Fig. 6 Duration of interval free of disease according to grade

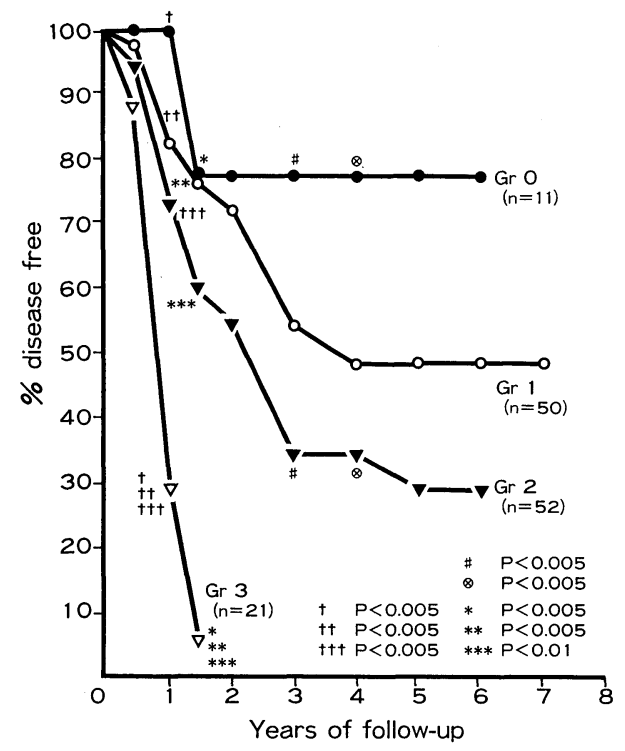

Fig. 7 Duration of interval free of disease according to operation method

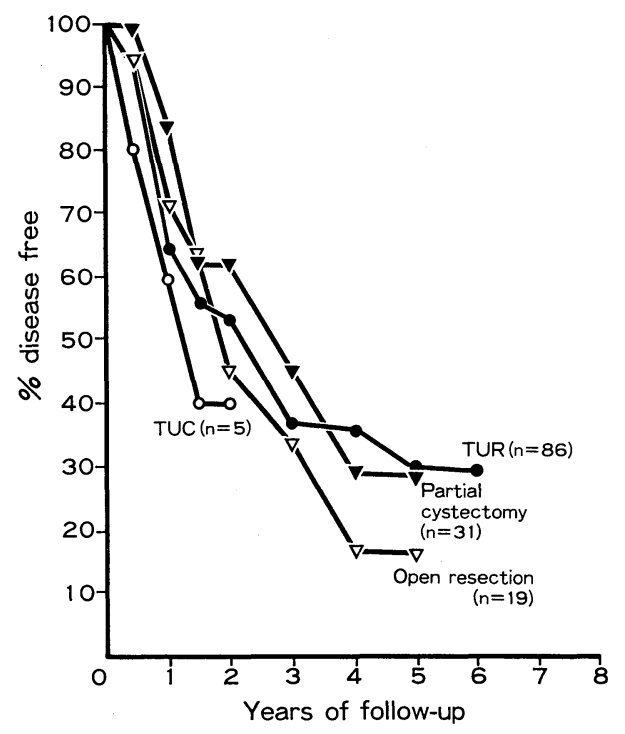

いては 1 年 : $16.7 \%, 2$ 年 : $37.5 \%, 3$ 年 : $55.4 \%$, 4 年〜 5 年: $70.2 \%$ であった. 1 年までは, 部分切除, 高位切開腫瘍切除, TUR, TUC の順に再発率が低く, 1 年以降は高位切開腫瘍切除の再発率の上昇がめだっ たが，各群間に有意差は認められなかった。

8) 手術十再発防止処置之再発率 (Fig. 8)

手術のみは33例 $(20.5 \%$ ), 手術 $+\beta$-glucuronidase 活性阻害剂(以下 SLA)の内服は16例 (9.9\%), 手術+ 制癌剤膀腅内注入療法 (以下膀注) は49例 $(30.4 \%$ ),

Fig. 8 Duration of interval free of disease according to various therapy

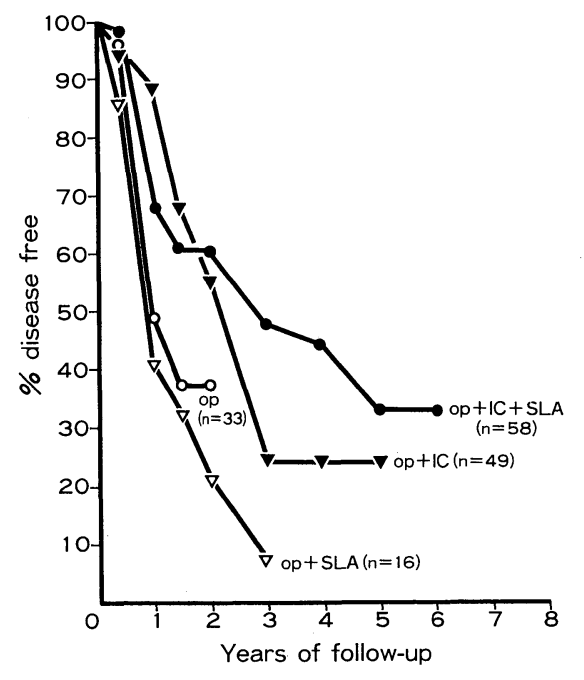


手術＋SLA＋膀注は58例（36\%）の分布を示した.

グラフより,1.5年までに非膀注療法群に再発率の著 明な上昇を認めた。をた膀注療法群に扣いても $2 \sim 3$ 年で再発率の上昇が認められた。全期間に括いて，手 術 $+\mathrm{SLA}+$ 膀注の群の再発率が低く, 次いで手術+膀 注, 手術のみ, 手術 + SLA の順であったが, 各治療群 間に打いて有意差は認められなかった。

\section{考 察}

膀胱腫瘍，特に表在性腫瘍は，膀胱保存手術後に高 い再発傾向を有し, 再発を繰り返す毎に深達度, 異型 度が増し予後不良となる症例もあり，取扱いに苦慮し ているのが現状である. 再発率に関して平松ら ${ }^{3)}$ は, 表 在性腫瘍55例の観察期間別の再発率として，6 カ月以 内の再発は $16.3 \%, 1$ 年以内では $25.4 \%, 3$ 年以内で は $38.6 \% ， 5$ 年では $35.4 \%$ と報告している。また九州 泌尿器科共同研究会4)がまとめた報告によれば，腫瘍 切除後未処置群 230 例の 1 年再発率は $38.3 \%, 3$ 年 $57.3 \% ， 5$ 年 $71.4 \%$ である. 大森ら ${ }^{5}$ は膀胼保存手術 278 例について，1 年再発率 $24.9 \% ， 2$ 年 $36.9 \% ， 3$ 年 $45.0 \%, 4$ 年 $50.4 \%, 5$ 年 $54.6 \%, 7$ 年 $66.1 \%, 10$ 年 $80.5 \%$ と報告している. $\mathrm{NBCCGA}^{6}$ の報告によれば, stage $\mathrm{O}$ と A 133例のらち, 1 年以内の再発は 44 例 $33 \%$ に認めている。ささら Pyrah ら”は 1 年再発率 $51 \%$, Gibbons ら ${ }^{8)}$ は78例中の再発率は67\%, Greene ら ${ }^{9}$ は 15年間の follow にて $73 \%$ ，Varkarakis ら ${ }^{10)}$ は stage $\mathrm{O}, \mathrm{A}, \mathrm{B} 1$ の 238 例を 3 年間 follow して $71 \%$ の再発率を 示している。このような高い再発率を有する原因とし て, Melicow ${ }^{11)}$ は, (1)切除や凝固時の取り残し, (2)手術 操作による播種, (3)癌原物質による新腫瘍発生の 3 通 りの説明をしている，(1)については，初発腫瘍に一致 した部位より，また術後早期に発生することよりある 程度鑑別が可能であるが，膀胱腫瘍ではいわゆる異所 性再発が多く認められ ${ }^{12) 13)}$ ，再発の主な原因として現 在では上記(2)すなわち implantation theory と, (3)す なわち multicentric theory が考兄られている6(14)15).

再発が予知できれば治療や再発防止処置もより積極 的に施行でき，予後の改善が期待できると考える.

著者らは, 初発腫瘍の内視鏡的因子, 組織学的因子, さらに治療因子の再発に及ぼす影響を検討した。

1）全症例の再発率

各期間の再発率については，諸家の報告5) 9) と同程 度であるが, Fig. 1のように 6 カ月から1.5年までの間 に打いて特に高い再発率を示し，この傾向は 3 年まで 続さ以降は徐々に減少している。すなわち， 3 年以後
は再発の危険性は少なくなるが， 3 年間は厳重に観察 する必要のあることが示唆された。

2）増殖様式と再発率

対象が表在性腫瘍であるので，分布に打いては乳頭 状腫瘍が $90.1 \%$, 非乳頭状腫瘍が $8.1 \%$ と乳頭状が多 かった．著者らの成績では，2 年までは乳頭状腫瘍が 非乳頭状腫瘍に比して再発率が高かったが，大森ら ${ }^{5)}$ の報告と同様に二群間に有意差は認めなかった。大森 らは，さらに乳頭状有茎性怙よび非乳頭状広基性に分 類して検討しているが，非乳頭状広基性が有意に高い 再発率を示したと報告している。

3) 数と再発率

腫瘍の数については，単発と 2 個以上の多発の 2 群 に分類した。多発性腫瘍は単発性腫汮に比べ高い再発

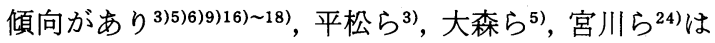
統計学的に有意差を認めている。多発性腫瘍は, 腫瘍 の発生招よび再発の原因として multicentric theory によりよく説明でき，再発率が高いことも容易に理解 できる。 $\mathrm{NBCCGA}^{6}$ は，再発に影響する因子は腫瘍の 大きさ, 深達度, 異型度ではなく多発性であるとして いる. Heney ら ${ }^{18) 19)}$ 女多発性を再発因子として報告し ているが，他に大きさ，粘膜固有層への浸潤，粘膜生 検での異常所見をあげている，著者らの成績では，各 期間に执いて多発群に再発傾向が強く疑われたが，検 定において有意差は認められなかった。

4）大ささと再発率

大きさが増すほど再発率が高くなるという報告が多 (45)918) 20). Greene ら ${ }^{9 /}$ は, $4 \mathrm{~cm}$ 以上の大きさの腫瘍は $100 \%$ の再発率があると報告しており, Heney ら ${ }^{18)}$ 58 例の $\mathrm{Ta}$ と $\mathrm{T} 1$ の表在性腫瘍の分析にて, $3 \mathrm{~cm}$ 以上 の大きさは再発に影響を与える因子として考学られる としている.さらに Heney ら ${ }^{199}$ は, 249例の分析で $5 \mathrm{~cm}$ 以上の大きさの腫瘍は再発し易いと述べている.

著者らの成績は, Fig. 4k示すように小さいものほ ぞ再発率が高い傾向にあり，諸家の報告と相反する結 果であった。この原因としては種々考えられるが, Fig. 9に示したように小さな腫瘍ほど経尿道的手術の占め る割合いが高く，大きくなるに従って膀脱全摘術の比 率が上昇し，Fig. 4の大きさと再発率の関係は膀胀全 摘術の占める割合いによる影響と考兄られた。

5）深達度と再発率

深達度と再発率の関係について平松ら ${ }^{3)}$, 朝日ら ${ }^{21)}$ は深達度が進行するに従い有意に高い再発率を示すと 報告している. Heney ら ${ }^{18) 19}$ は $\mathrm{Ta}$ と T1の腫瘍につ 
いて検討し, T1腫瘍は 5 年以内に $95 \%$ 再発し, 粘膜固有 層への浸潤の有無が再発に及ぼす影響は大きいとして いる．著者らの成績でも深達度が進むにつれて再発率 が増す傾向にあり，特に 2 年から 4 年までにおいて pT1と pTisの 2 群間に有意差が認められた。

6) 異型度と再発率

著者らの成績において, 異型度については深達度と 比較して，再発への影響が著明に認められた。すなわ ち異型度が進むにつれ再発率は急激に上昇し, 統計学 的にも 1 年から 1.5 年までにおいて G3と $\mathrm{G} 0, \mathrm{G} 1, \mathrm{G} 2$ の 各群に, 3 年から 4 年までに扔いて $\mathrm{G} 2$ と $\mathrm{G} 0$ の間に有 意差が認められた。朝日ら ${ }^{21)}$ は異型度が増す毎に再発 率が有意に高くなることを報告し，平松ら ${ }^{3)}$ は，有意差 はないが同様の傾向があるとした，異型度は再発に影 響を与古る因子として考兄られている1920). Smith $ら^{22)}$ は筋層に浸潤している腫瘍についてのみ $\mathrm{G} 3$ が再 発をきたしやすいとし，限定した腫瘍では異型度は再 発に影響を及ぼすとした。

著者らの成績でも, 異型度により再発率の著明な差 が認められて扣り，異型度は再発に大きく影響してい ると考兄られた。

7) 手術術式と再発率

膀胼保存的手術について，それぞれの再発率を検討 した. 1 年までは部分切除, 高位切開腫瘍切除, TUR, TUC の順に再発率が低く，1 年以降は高位切開腫瘍 切除の再発率の上昇がめだったが，各群間に有意差は 認められなかった。諸家の報告でも経尿道的手術が良 いとするもの ${ }^{2123)}$, 部分切除が良いとするもの ${ }^{17)}$, 術式 による差は認められないとするもの ${ }^{24)}$ と種々である が，各施設に拈ける術式の選択基準や背景因子が統一 されていないので,一様に比較することは困難である. 著者らも背景因子毎に検討を加える必要があるが，各 群の症例数が少なくなるために生じる誤差が大きくな り, 今回は省略した。症例数の追加により今後検討す べき課題であろうと考える.

\section{8）手術十再発防止処置と再発率}

再発防止処置として, SLA 群, 膀注群, SLA+膀注 群の 3 群に分けた. Fig. 8より1.5年までにおいて, 非 膀注群は膀注群に比して有意差は認めなかったものの 再発傾向が強かった. しかし膀注群に沶いても2-3 年 で再発率が上昇し，この時期での何らかの再発防止処 置が必要であることが示唆された. 膀胱保存的手術後 の制癌剤膀注による再発抑制効果は，すでに多くの報 告により認められている425) 29). さらに非膀注群との
Fig. 9 Operation methods according to size

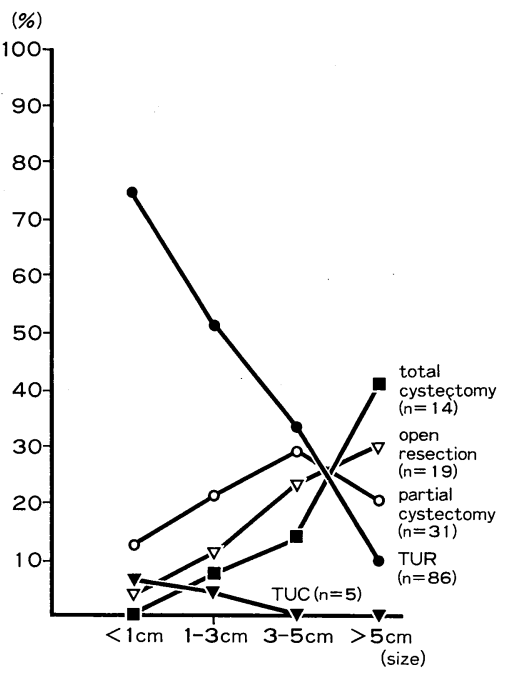

Fig. 10 Intervals of recurrent cases

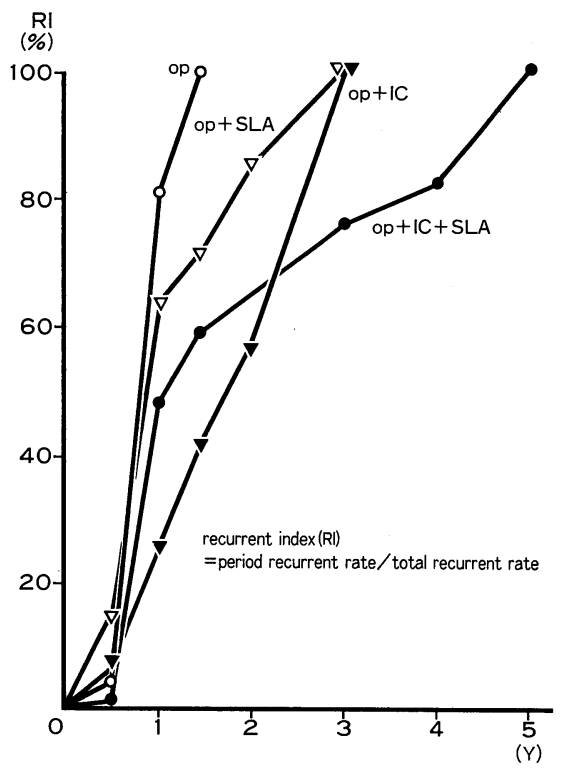

randomized trial によっても再発抑制効果が証明され ている30) 32). 当科に打いては, 術後一定期間のみ膀注 を施行していたが，今後は間歇的継続投与の必要性が 考光られる。

SLA の内服による再発抑制効果について片山 ${ }^{33}$ は, 早期再発については抑制効果はないが 3 年では有意に 効果があったとした. しかし村田ら $\left.{ }^{34}\right)$ は, 治療開始後 1 年間の観察に怙いて再発は対照群に比べて低かった が, 長期の観察では差は認めなかったと報告している。 
朝日ら ${ }^{35)}$ も約 10 年に渡る長期間の観察にて, SLA 内服 による再発抑制効果は認められなかったと報告してい る.このようにSLA 内服の効果については意見の一 致をみていない，著者らの成績でも手術単独群と手術 にSLA 内服を加えた群の間では, 再発率に差は認め られなかったが, 膀注にSLA を加えた群は膀注単独 群と比較し再発がある程度抑制される傾向が認められ た.

著者らは再発例について，その再発までの期間を検 討した. Fig. 10は綐軸に recurrent index（RI）を, 横軸は再発時期を示した. RI は, actuarial methodに より求めた各期間までの再発率を最経観察期間までの 再発率で割ったもので, 各期間までの再発例の比率を 表わしている。この図より手術のみの群の再発は，す べて1.5年末満に発生しているが, SLA や膀注を加兄 ることにより再発抑制期間の延長が認められ，手術に 膀注とSLA の両者を加えた群は，さらに再発抑制効 果が認められた。

以上各因子毎に考察を加えたが，再発に影響を及ぼ す他の因子として，Smith ら ${ }^{22)}$ は，Ta, T1の正常粘膜 4 力所を生検し，1 1 所またはそれ以上に異常所見が ある症例は，所見がなかった症例よりも有意に再発の 機会が多いと報告している，また Murphy ら ${ }^{36)}$ は，有 意差はないが生検の結果は再発を予知できると報告し ているように，正常と思われる粘膜の生検による組織 像が報告されている818)19200). 腫瘍発生時に，一見正常 と思われる粘膜には，すでに前癌状態ともいうべき増 殖性変化や異型性が認められることは以前より知られ ている1137) 40)。これは multicentric theoryを裏づけ る事実でもあり, 再発に与える影響は大きいと考学る。 implantation theoryによる再発は, 初発と再発の部 位の違いにより説明されている。 Heney ら ${ }^{18)}$ は, 初発 腫崵が頂部にみられることは立常に少ないが，再発腫 疸は $29 \%$ が頂部にみられ，さらにWeldon ら ${ }^{411}$ は，再 発腫瘍が前壁, 後壁, 頂部に発生することは切除鏡や 膀胼鏡, カテーテルの先で, さらには経尿道的切除の 際の頂部にたまったガスにより，損傷した尿路上皮へ の腫瘍細胞の implantation が考党易いと報告してい る.

implantation の予防の為には, 経尿道的切除後の充 分な膀胱洗浄に加兄, 術後直ちに，あるいはなるべく 早期よりの膀注療法が必要であり,さらに multicentric な腫瘍再発を抑制する為に長期に渡る継続投与が 必要であると考える.

\section{結語}

pT2以下の表在性膀胱腫崵161例の再発率について 分析し以下の結果を得た。

1. 表在性膀胱腫瘍全体に拈いて, $0.5 \sim 1.5$ 年に著明 な再発傾向を示した。

2. 乳頭状腫瘍, 非乳頭状腫瘍に拈いては再発率に有 意差を認めなかった。

3. 単発, 多発に捺いても再発率に有意差を認めな かった。

4. 組織学的深達度において， $2 \sim 4$ 年では $\mathrm{pT} 1$ は pTis より有意な再発傾向を示したが，それ以外では再 発率に有意差を認めなかった。

5. 組織学的異型度に括いて, $1 \sim 1.5$ 年で $\mathrm{G} 3$ は $\mathrm{G} 0$, G1, G2に対し， $3 \sim 4$ 年で G2は G0に対し有意な再発 傾向を示した。

6. 手術術式においては, 各術式の再発率に有意差を 認めなかった。

7. 膀脱腔内注入療法群において, $2 \sim 3$ 年で著明な 再発傾向を示し，この期間での再発防止処置の必要性 が示唆された。

8. 手術のみ, 手術十膀注, 手術 SLA, 手術十 $\mathrm{SLA}+$ 膀注の各治療群に招いては, 手術+SLA+膀注 が再発抑制効果といら点で最も優れていた，再発例に ついてみると,手術のみでは再発はすべて 1.5 年末満に おこり, SLA および膀注を加えることにより再発防止 期間の延長が認められた。

\section{文献}

1) Cutler, S.J. and Ederer, F.: Mazimum utilization of life table method in analyzing survival. J. Chronic, Dis., 8, 699-712, 1958.

2) 日本泌尿器科学会, 日本病理学会編：泌尿器科。病 理膀胱癌取り扱い規約，第一版，金原出版，東京， 1980.

3）平松 㑆，岡島英五郎，本宮善恢，入矢一之，伊集 院真澄, 近藤徳也, 平尾佳彦, 松島 進：膀胱腫場 に関する臨床的研究。第 II 報, 表在性膀胱腫瘍の 再発㵝関する臨床統計的観察。日泌尿会誌，64, 287-294, 1973.

4) 丸州泌尿器科共同研究会：マイトマイシン C 膀胱 内注入による膀胱腫瘍の再発防止効果. 西日泌尿, 36, 535-539, 1974.

5）大森弘之, 藤田幸利, 池 紀征, 朝日俊彦, 尾崎雄 治郎, 西 光雄, 棚橋豊子, 万波康介, 陶山文三, 吉本 純, 松村陽右, 白石哲郎, 片山泰弘：膀胼腫 湯の再発に関する臨床統計的観察。第 1 報：とく に膀胱鏡所見による再発率について，泌尿紀要， 24, 469-474, 1978. 
6) National Bladder Cancer Collaborative Group A : Surveillance, initial assessment and subsequent progress of patients with superficial bladder cancer in a prospective longitudinal study. Cancer Research, 37, 2907-2910, 1977.

7) Pyrah, L.N., Raper, F.P. and Thomas, G.M.: Report of follow up papillary tumors of the bladder. Brit. J. Urol., 36, 14-25, 1964.

8) Gibbons, R.P., Mandler, J.I. and Hartman, W. H.: The significance of epithelial atypia seen in non-invasive transitional cell papillary tumors of the bladder. J. Urol., 102, 195-199, 1969.

9) Greene, L.F., Hanash, K.A. and Farrow, G.M. : Benign papilloma or papillary carcinoma of the bladder : ? J. Urol., 10, 205-207, 1973.

10) Varkarakis, M.J., Gaeta, J., Moore, R.H. and Murphy, G.P.: Superficial bladder tumor: Aspects of clinical progression. Urology, 4, 414 $-420,1974$.

11) Melicow, M.M.: Histological study of vesical urothelium intervening between gross neoplasms in total cystectomy. J. Urol., 68, 261 $-279,1952$.

12) Melicow, M.M.: Tumors of the urinary bladder : A clinicopathological analysis of over 2500 specimens and biopsies. J. Urol., 74, 498-520, 1955.

13) Lerman, R.I., Hutter, R.V.P. and Whitmore, W. F. : Papilloma of the urinary bladder. Cancer, 25, 333-342, 1970.

14) Kaplan, J.H., Mcdonald, J.R. and Thompson, G. $\mathrm{J}$. : Multicentric origin of papillary tumors of the urinary tract. J. Urol., 66, 792-804, 1951.

15) Boyd, P.J.R. and Burrand, K.G.: Site of bladder-tumor recurrence. Lancet, 30, 1290-1292, 1974.

16) Kretschmer, H.L , Barringer, B.S., Braasch, W. F., Dean, A.L., Ferguson, R.S., Keyes, E.L. and Smith, G.G.: Cancer of the bladder. A study based on 902 epithelial tumors of the bladder in the carcinoma registry of the american urological association. J. Urol., 31, 423-472, 1934.

17）鈴木騏一, 杉田篤生, 三浦忠雄, 加藤正和, 小野寺 豊, 矢吹日出雄, 加藤輝彦：膀胱癌に対する膀胼部 分切除術の臨床的ならびに病理組織学的研究. 第 1 報. 膀胱部分切除術施行症例の臨床像ならびに 遠隔成績。日泌尿会誌，57，380-387， 1966.

18) Heney, N.M., Nocks, B.N., Daly, J.J., Prout, G. R. Jr., Newall, J.B., Griffin, R.P., Perrone, T.L. and Szyfelbein, W.A.: Ta and T1 bladder cancer: Location, recurrence and progression. Brit. J. Urol., 54, 152-157, 1982.

19) Heney, N.M., Ahmed, S., Flanagan, M.J., Frable, W., Corder, M.P., Hafermann, M.D. and Hawkins, I.R.: Superficial bladder cancer. Progression and recurrence. J. Urol., 130, 3083 -1086, 1983.

20) Prout, G.R.: The philosophy of National Bladder Cancer Project studies. Clinical bladder cancer. Plenum Press, New York, London, 1982.

21）朝日俊彦, 池 紀征, 尾崎雄治郎, 西 光雄, 棚橋 豊子, 万波廉介, 陶山文三, 吉本 純, 藤田幸利, 大森弘之, 松村陽右, 白石哲郎, 片山泰弘：膀胼腫 瑒の再発関する臨床統計的観察. 第 2 報, 手術術 式別㧍よび病理組織像による再発率について，泌 尿紀要，24，713-719，1978.

22) Smith, G., Elton, R.A., Beynon, L.L., Newsam, J. E., Chisholm, G.D. and Hargreave, T.B.: Prognostic significancnce of biopsy results of normal-looking mucosa in cases of superficial bladder cancer. Brit. J. Urol., 55, 665-669, 1983.

23）大北健逸：電気凝固術. 臨泌, 21, 766-769, 1967.

24）宮川美栄子, 原田 卓, 吉田 修, 加藤篤二：膀胱 腫崵の再発に関する臨床統計的観察. 泌尿紀要, 16, 731-737, 1970.

25）冨山哲郎：膀胖癌に対する抗腫瘍剤膀胱内注入療 法の臨床的研究. 日泌尿会誌, 63, 497-518, 1972.

26）加野資典, 伊藤泰二：TUR-Bt $($ 経尿道的膀胱腫場 切除術）後の制癌剂膀胼内注入療法による異所性 再発予防効果について. 臨泌, 27, 403-406-1973.

27）三品輝男, 都田慶一, 荒木博孝, 藤原光文, 小林徳 郎, 前川幹雄 : 膀胱癌に対する膀腅内注入療法. 癌 の臨床, 25, 845-855, 1979.

28）新村研二, 早川正道, 藤岡俊夫, 置塩則彦, 山越 剛, 名出頼男: 膀胱腫瘍再発防止を目的とした Mitomycin C の膀腅内注入療法の臨床的観察. 臨 泌， 34, 749-753， 1980.

29）香川 征, 沼田 明, 前林浩次, 滝川 浩, 湯线 誠, 橋本寛文, 炭谷晴雄, 斉木 喬: Carboquone と Cytosine Arabinosideの併用による膀腅内注 入の再発予防効果. 泌尿紀要, 27, 1099-1102, 1981.

30）尾関全彦, 田崎 寛, 松永重昂, 矢島暎夫, 河村信 夫, 木村茂三, 東福寺英之, 大越正秋：膀胖腫場の 再発に対する制癌剂予防注入法の効果. 臨泌, 23, 475-482, 1969.

31) Kemeny, N., Yagoda, A., Wang, Y., Field, K., Wrobleski, H. and Whitmore, W.: Randamized trial of standard therapy with or without PolyI : $\mathrm{C}$ in patients with superficial bladder cancer. Cancer, 48, 2154-2157, 1981. 
32) Burk, K., Troller, R.M. and Pittner, P.: Recurrence prophylaxis in non-invasive urinary bladder carcinoma: Experience with 400 patients. Urologe A., 22, 332-336, 1983.

33）片山泰弘：膀胱腫瘍再発予防に関する研究. 第 1 報, 尿中 $\beta$-Gluculonidase 活性阻害剂 2,5-di-oacetyl, D-glucaro (1-4) (6-3) dilactone 投与によ る膀胼腫瘍再発抑制に関する臨床的, 実験的研究 一特に長期投与例を中心として一。 日泌尿会誌, 63，951-971，1972.

34）村田庄平, 三品輝男, 大江 宏, 渡辺康介, 高橋 徹, 秋山喜久夫：膀胱癌に関寸る研究一術後再発 予防についての検討一, 泌尿紀要, 23，47-50, 1977.

35）朝日俊彦, 藤田幸利, 池 紀征, 尾崎雄次郎, 棚橋 豊子, 陶山文三, 吉本 純, 宮田和豊, 大森弘之, 松村陽右, 西 光雄, 片山泰弘: 膀胱腫瘍の再発に 関する臨床統計的観察. 第 4 報. SLA およびビタ ミン B6内服の再発に拈よばす影響について. 泌尿 紀要, 25, 143-148, 1979.

36) Murphy, W.M., Nagy, G.K., Rad, M.K., Soloway, M.S., Parija, G.C., Cox, C.E. and Friedell, G.H.: Normal urothelium in patients with bladder cancer. A preliminary report from the National Bladder Cancer Collaborative Group A. Cancer, 44, 1050-1058, 1979.

37）市川篤二, 过 一郎, 石井澄子：膀胱腫瘍の際の腫 瘍近接部, 遠隔部及び後部尿道粘膜の態度. 特に上 皮化生と腫瘍との関係に就て．日泌尿会誌，43, 19-27, 1952.

38) Simon, W., Cordnnier, J.J. and Snodgrass, W. T.: The pathogenesis of bladder carcinoma. J. Urol., 88, 797-882, 1962.

39) Schade, R.O.K. and Swinney, J.: The association of urothelial atypism with neoplasia: Its improtance in treatment and prognosis. J. Urol., 109, 619-622, 1973.

40) Koss, L.G., Tiamson, E.M. and Robbins, M.A. : Mapping cancerous and precancerous bladder changes. A study of the urothelium in teh surgically removed bladders. J.A.M.A., 227, 281-286, 1974.

41) Weldon, T.E. and Soloway, M.S.: Susceptibility of urothelium to cellular implantation. Urology, 5, 824-827, 1975.

（1984年11月 6 日受付） 